\title{
Distribution of radionuclides in modern sediments of the rivers flowing into the Dnieper-Bug Estuary
}

\author{
Tetiana Alokhina ${ }^{1,2, *}$, and Vadym Gudzenko ${ }^{3}$ \\ ${ }^{1}$ State Scientific Institution "Center for Problems of Marine Geology, Geoecology and Sedimentary Ore Formation National Academy of \\ Sciences of Ukraine", Section of geology and environmental problems of ore deposits, Kryvyi Rih, Ukraine \\ ${ }^{2}$ Kryvyi Rih State Pedagogical University, Kryvyi Rih,, Ukraine \\ ${ }^{3}$ State Scientific Institution "Institute of geological science of the National Academy of Science of Ukraine”, Kyiv, Ukraine
}

\begin{abstract}
The article presents the results of large-scale studies of the content and distribution of natural and man-made radionuclides in the sediments of the rivers flowing into the Dnieper-Bug estuary. The article also presents the results of the granulometric analysis of the surveyed water bodies. The data about natural radioactive elements in the sediments rivers flowing into the Dnieper-Bug estuary obtained in this research are demonstrated moderate specific activity, which, however, clearly correlates with the granulometric composition of sediments. The ${ }^{137} \mathrm{Cs}$ determined by us is contained in the sediments of all studied water bodies and the places of it greatest concentration coincide with the areas in which the sediment is represented mainly by the pelitic fraction. The data obtained in this research can serve as a baseline data in natural radionuclides concentration in sediments rivers flowing into the Dnieper-Bug estuary. The obtained data can also be used for further monitoring of the specific activity of man-made radionuclides, in particular ${ }^{137} \mathrm{Cs}$.
\end{abstract}

\section{Introduction}

Aquatic ecosystems play an important role in the migration of both natural and artificial radionuclides, as well as in their redistribution. On the one hand, they play the role of transport arteries for migration radionuclides within the reservoir and adjacent ecosystems, on the other hand, they are natural barriers to the deposition of a certain amount of radionuclides [1].

The barrier role of hydroecosystems is determined by the nature of the reservoir, the quality and intensity of the processes that take place in it. The main ones are the volume and depth of the water column, the flow rate, biological productivity, the composition of sediments, the intensity of sedimentation, the presence of geochemical barriers, as well as the amount of biomass and species composition of aquatic organisms. Equally important for the value of the barrier function of aquatic ecosystems are the physicochemical and biogeochemical properties, the mobility of the radionuclides themselves, the intensity of their sorption and accumulation by the abiogenic and biogenic components of aquatic ecosystems [2].

Bottom sediments of reservoirs and watercourses, to a large extent, fulfill the mission of depositing substances entering the water from catchment areas during coastal erosion and runoff from adjacent areas. Thus, composition of sediments reflects the ecological state of rivers and their catchment areas. Natural radionuclides in bottom sediments reflect the geochemical features of the region. Man-made radionuclides, which include ${ }^{137} \mathrm{Cs}$ and ${ }^{90} \mathrm{Sr}$, are of artificial origin, the pollution by them is carried out mainly by air way, to a lesser extent, waterways.

The relevance of the presented studies is determined by the decision to build the E-40 channel $[3,4]$. The E-40 waterway is a transnational initiative aiming to link the Baltic and Black Seas by an approximately $2,000 \mathrm{~km}$ long navigable connection running from Gdansk in Poland to Kherson in Ukraine. This proposes that the route would go through the river systems of Vistula, Bug, Pina, Pripyat and Dnieper. Several parts of planned route would need to be straightened, dammed, dredged, or drained.

Analysis of radioactivity in Polesia has been carried out by experts from «Association pour le Contrôle de la Radioactivité dans l'Ouest» (ACRO) [4, 5]. More than 35 years after Chernobyl accident, residual radioactive contamination is such that people are prohibited to live in an extensive exclusion zone. At the present time, contamination is dominated by cesium-137, strontium-90 and various isotopes of the highly toxic plutonium. Cesium-137 binds to clay sediments (pelitic fraction), while strontium-90 is more mobile.

The whole Pripyat-Dnieper watershed was contaminated by nuclear fallout. Dominating contaminants are cesium-137 and strontium-90. First one has tend to be fixed in bottom sediments, unlike second is continuously transported down to the Black Sea through the Dnieper cascade. Sediments contaminated by cesium137 have been slowly covered by less contaminated and clean sediments, offering a natural shield to this pollutant. The International Atomic Energy Agency (IAEA)

\footnotetext{
* Corresponding author: Alohkina@gmail.com
} 
recommends leaving these sediments in place and avoiding processes that will lead to their resuspension.

Downstream of the Chernobyl exclusion zone, the Dnieper river serves as a water source for approximately 8 million Ukrainians and its waters are used to irrigate crops consumed by as many as 20 million people.

The section of the E-40 waterway running from the Kiev reservoir to the Black Sea would require regular dredging work. However, the feasibility study on the proposed E-40 waterway failed to consider some of the major dangers posed by radiation. Experts provided an initial evaluation of the impact of the construction and maintenance of the E40 waterway on the distribution of radioactive material. Among other things, they point to, that E-40 waterway risks disturbing several radiation hotspots. International Atomic Energy Agency recommends leaving contaminated sediment undisturbed $[4,5]$.

Thus, the aim of our researches were determination of specific radioactivity and distribution of natural and man-made radionuclides in modern sediments of the rivers flowing into the Dnieper-Bug estuary. The data obtained in this study may serve as a baseline data of radionuclide concentration in modern sediments of the researched rivers and water reservoirs.

\section{Literature review}

Determination of specific radioactivity and total $\beta$ activity of sediments allows to establish the intensity of anthropogenic impact, identify areas with high content of natural or man-made radionuclides, monitor the level of contamination of areas - i.e. is a widely used method of environmental research.

River sediment depositions on the bottom of rivers most frequently consist of sand and gravel particles with different grain sizes, which make them particularly valuable for the building construction. Knowledge of radioactivity present in building material enables one to assess any possible radiological hazard to mankind by the use of such materials. In the review [6], the natural radionuclide $\left({ }^{238} \mathrm{U},{ }^{232} \mathrm{Th}\right.$ and $\left.{ }^{40} \mathrm{~K}\right)$ contents have been analyzed for the sediment samples of Ponnaiyar River. In the presented study, the dose rate was calculated, as well as the mineralogical characteristics of the sediment were investigated. The results obtained in the study suggest that the level of natural radioactivity of the present sediments mainly depends upon the amount of kaolinite (clay). Mineral characterization of various grain sized sediments show clay and magnetic minerals are rich in lower grain sized $(\leq 120 \mu \mathrm{m})$ samples.

The effect of sediment grain size, mineralogy, composition of the acid-extractable materials on the distribution of ${ }^{7} \mathrm{Be},{ }^{10} \mathrm{Be},{ }^{137} \mathrm{Cs}$, and unsupported ${ }^{210} \mathrm{~Pb}$ in detrital sediment samples collected from rivers in China and the United States were examined by authors in the presented research [7]. Acid-extractable materials (made up predominately of $\mathrm{Fe}, \mathrm{Mn}, \mathrm{Al}$, and $\mathrm{Ca}$ from secondary minerals and grain coatings produced during pedogenesis) are positively related to the abundance of fallout radionuclides in sediment samples. Grain-size dependency of fallout radionuclide concentrations was significant in detrital sediment samples. Authors conclude that time-dependent geochemical, pedogenic, and sedimentary processes together result in the observed differences in nuclide distribution between different grain sizes and substrate compositions. These findings likely explain variability of measured nuclide activities in river networks as well as spatial and temporal differences in erosion rates and processes.

Discharges from the Krasnoyarsk Mining and Chemical Industrial Complex near Krasnoyarsk resulted in radioactive contamination of sediments of the River Yenisei. Between 1999 and 2006, 16 sediment cores were collected at different positions $15-1500 \mathrm{~km}$ downstream from the discharge point. Contamination levels of artificial radionuclides were decreasing with increasing distance downstream the Krasnoyarsk Mining and Chemical Industrial Complex: the fastest decrease of average activity by a factor of 10 over a distance of $300 \mathrm{~km}$ was observed for ${ }^{241} \mathrm{Am}$, whereas for ${ }^{137} \mathrm{Cs}$ this decrease occurred over a distance of $1100 \mathrm{~km}$. Sequential extraction experiments revealed that in all depths and at all distances the studied radionuclides were tightly bound to the sediment [8].

The results of a radioecological study of six small rivers located in the impact zone of the Beloyarsk Nuclear Power Plant (BNPP) and the cooling reservoir of the BNPP are presented [9]. The activity of 21 radionuclides was determined, as well as the total $\alpha$ - and $\beta$-activity in the main components of aquatic ecosystems. It is shown that after the decommissioning of blocks I and II of the BNPP, the content of ${ }^{137} \mathrm{Cs}$ in water, bottom sediments, ichthyofauna and macrophytes of the Beloyarsk reservoir decreased by tens and hundreds of times. The fundamental significance of this phenomena lies in the fact that in a large time range two mechanisms work: selfpurification of the aquatic ecosystem from radionuclides due to the decay of radioactive substances and mechanism of redistribution of radionuclides from water to other components, primarily into bottom sediments.

The report [10] is devoted to the study of the activity of the natural radionuclides ${ }^{40} \mathrm{~K},{ }^{232} \mathrm{Th},{ }^{226} \mathrm{Ra}$ and technogenic ${ }^{137} \mathrm{Cs}$ radionuclide in the river sediments of watercourses around the Lomonosov diamond deposit (northwestern Russia). Samples of river sediments and surface waters were taken from the Zolotitsa River and its tributaries in the area of the diamond deposit. The average activity of ${ }^{137} \mathrm{Cs},{ }^{226} \mathrm{Ra},{ }^{232} \mathrm{Th}$ and ${ }^{40} \mathrm{~K}$ were 5,$4 ; 9,0 ; 11,2$; $318.8 \mathrm{~Bq} / \mathrm{kg}$, respectively. Several patterns of radionuclide accumulation have been found depending on the physicochemical parameters of river sediments. These patterns are due to the technogenic influence of the mining and beneficiation complex. The performed studies present the evaluation of the impact of diamond mining on natural radionuclides' distribution and accumulation in the river sediments within the adjacent territories.

The report on the concentrations of radionuclides ${ }^{40} \mathrm{~K}$, ${ }^{137} \mathrm{Cs}{ }^{232} \mathrm{Th}$ and ${ }^{226} \mathrm{Ra}$ in river sediments along the Arvand river of Iran for future environmental monitoring was shown. Sediments were collected from 20 sites. The mean concentration activity for ${ }^{40} \mathrm{~K},{ }^{137} \mathrm{Cs}^{232} \mathrm{Th}$ and ${ }^{226} \mathrm{Ra}$, were 
280,$91 ; 5,96 ; 16,47$ and $16,10 \mathrm{~Bq} / \mathrm{kg}$ dry weight, respectively. The values of radiation hazard parameters were comparable to the world averages and below the recommended values. The data obtained in this study will serve as a baseline data in natural radionuclide concentration in sediments along the Arvand river [11].

In the paper [12] authors present distribution of natural gamma-active nuclides $\left({ }^{40} \mathrm{~K}\right)$, elements of uranium ${ }^{238} \mathrm{U}$ rows $\left({ }^{214} \mathrm{~Pb},{ }^{214} \mathrm{Bi},{ }^{226} \mathrm{Ra}\right)$, elements of thorium ${ }^{232} \mathrm{Th}$ rows $\left({ }^{212} \mathrm{~Pb},{ }^{212} \mathrm{Bi},{ }^{228} \mathrm{Ac},{ }^{208} \mathrm{Tl}\right)$, and technogenic ${ }^{137} \mathrm{Cs}$ in the bottom sediments of the small rivers of the National natural park «Zacharovannij kraj». It is shown that content of these elements in the bottom sediments is relatively stable and can be examined as base-line, it is proportional to the siltation level of the small rivers and largely depends on their morphology. Total specific activity of natural gamma-active nuclides (without taking into account ${ }^{40} \mathrm{~K}$ ) in the bottom sedimentations is within of $126-184 \mathrm{~Bq} / \mathrm{kg}$. Averaged data of heavy metals content and specific activity of radionuclides in the bottom sediments of the small rivers are used for mapping of this protected territory and for the prediction of migration. Also these data apply for identification of the investigated areas of the rivers taking into account the geochemical features of the region.

The Rhone River is one of the most nuclearized river in the world. Radionuclide concentrations in water and suspended sediments transferred to the marine environment were intensively monitored in this river over the last decades (2002-2018). While $>60 \%$ of plutonium, americium, cesium, cobalt, silver, beryllium and actinium radioisotopes are carried by sedimentary particles, sodium, tritium, antimony and strontium are mainly exported as dissolved species $(>90 \%)$ due to their low affinity with particles. The concentrations of numerous anthropogenic radionuclides originating from nuclear industries significantly have declined since the beginning of the 2000s were shown [13]. If no change of the current anthropogenic and climatic pressures, the time required for a reduction by half the concentrations in the downstream part of the Rhône River, would be close to 6 years for most artificial radionuclides. The exception is for tritium and other artificial radionuclides conveyed to the river by soil leaching and erosion $\left({ }^{90} \mathrm{Sr},{ }^{241} \mathrm{Am}\right.$, plutonium isotopes), their half-life would be far longer.

Vertical profiles of environmental radionuclides $\left({ }^{210} \mathrm{~Pb},{ }^{137} \mathrm{Cs},{ }^{238} \mathrm{U},{ }^{232} \mathrm{Th},{ }^{226} \mathrm{Ra}\right.$ and $\left.{ }^{40} \mathrm{~K}\right)$ in a sediment core (Y1) of the Yellow River Estuary wetland were investigated to assess whether environmental evolutions in the coastal wetland could be recorded by the distributions of radionuclides. Based on ${ }^{210} \mathrm{~Pb}$ and ${ }^{137} \mathrm{Cs}$ dating, the average sedimentation rate of core Y1 was estimated to be $1.0 \mathrm{~cm} \mathrm{y}^{-1}$. Vertical distributions of natural radionuclides $\left({ }^{238} \mathrm{U},{ }^{232} \mathrm{Th},{ }^{226} \mathrm{Ra}\right.$ and $\left.{ }^{40} \mathrm{~K}\right)$ changed dramatically, reflecting great changes in sediment input. Concentrations of ${ }^{238} \mathrm{U},{ }^{232} \mathrm{Th},{ }^{226} \mathrm{Ra}$ and ${ }^{40} \mathrm{~K}$ all had significant positive relationships with organic matter and clay content, but their distributions were determined by different factors. Environmental changes such as river channel migrations and sediment discharge variations could always cause changes in the concentrations of radionuclides. Frequent seawater intrusion decreased the concentration of ${ }^{226} \mathrm{Ra}$ significantly. The value of ${ }^{238} \mathrm{U} /{ }^{226} \mathrm{Ra}$ tended to be higher when the sedimentation rate was low and tide intrusion was frequent. In summary, environmental evolutions in the estuary coastal wetland could be recorded by the vertical profiles of natural radionuclides [14].

Thus, it can be noted that the determination of the specific activity of natural and man-made radionuclides in sediments is used to solve various scientific and applied problems.

A study which determined the activity concentration of ${ }^{137} \mathrm{Cs}$ in sediments contaminated by effluents from the Chernobyl accident which had collected along the coast of the Eastern Black Sea region in Turkey was carried out in 1993. Marine sediment samples were collected in 2015 from the same fifteen sampling points, and the activity concentrations of ${ }^{226} \mathrm{Ra},{ }^{232} \mathrm{Th},{ }^{40} \mathrm{~K}$ and ${ }^{137} \mathrm{Cs}$ were determined for the sediment samples. The activity concentrations ranged from 10,94-25,95, 12,14-33,05, $265,74-459,89$ and $2,08-37,45 \mathrm{~Bq} / \mathrm{kg}$ for ${ }^{226} \mathrm{Ra},{ }^{232} \mathrm{Th},{ }^{40} \mathrm{~K}$ and ${ }^{137} \mathrm{Cs}$ respectively. The results showed that there was a steep decline in ${ }^{137} \mathrm{Cs}$ within the sediment at most of the sampling sites from the Eastern Black Sea region during the 22-year period [15].

A recent study along the northern Black Sea coast with combined using of artificial $\left({ }^{137} \mathrm{Cs},{ }^{238,239+240,241} \mathrm{Pu},{ }^{241} \mathrm{Am}\right)$ and naturally occurring $\left({ }^{210} \mathrm{~Pb} /{ }^{226} \mathrm{Ra},{ }^{40} \mathrm{~K}\right)$ radionuclides as tracers for dating has allowed to reveal in sediment increase radioactive contamination of this basin with 137Cs after the Chernobyl accident. This is presumably caused by the prolonged input of the man-made radionuclides that showed a rise in the late 1990s - early 2000s, and by a possible post-deposition remobilization of ${ }^{137} \mathrm{Cs}$ from the seabed [16].

Radiation contamination sediments of the rivers flowing into the Dnieper-Bug estuary occurred due to aerosol falls on the water area, as well as a result of partial removal of radionuclides by the Dnieper and Southern Bug and due to leakage from polluted watersheds. Thus, according to the National Report on the state of man-made and natural safety in Ukraine [17], the radiation status of water bodies in the Dnieper basin in 2016, as in other years after the Chernobyl accident, was determined mainly by man-made radionuclides.

The main route for the entry of radionuclides into the Kyiv Reservoir with subsequent migration along the Dnieper River is the waters of the Pripyat River. Along the length of the Dnieper cascade of reservoirs due to the processes of sedimentation and dilution of the Dnieper water with cleaner waters of the side tributaries, the content of radionuclides decreases. In the water of the Kakhovka Reservoir near the town of Nova Kakhovka, the average concentration of ${ }^{90} \mathrm{Sr}$ in 2016 was $21 \mathrm{~Bq} / \mathrm{m}^{3}$, which is 4,2 times less than in the water of the Pripyat River. The average concentration of ${ }^{137} \mathrm{Cs}$ was 0,72 $\mathrm{Bq} / \mathrm{m}^{3}$, which is 47 times less than in Pripyat water. In the Dnieper-Bug estuary near the town of Ochakiv, the average ${ }^{90} \mathrm{Sr}$ content per year was $10,4 \mathrm{~Bq} / \mathrm{m}^{3}$, and ${ }^{137} \mathrm{Cs}-$ $4,8 \mathrm{~Bq} / \mathrm{m}^{3}$. The average concentration of ${ }^{90} \mathrm{Sr}$ in the water of the Southern Bug near Mykolayiv was $6,7 \mathrm{~Bq} / \mathrm{m}^{3},{ }^{137} \mathrm{Cs}$ $-2,7 \mathrm{~Bq} / \mathrm{m}^{3}$. 
As a result of sedimentation of water-suspended particles, radionuclides migrating from the Pripyat River along the Dnieper are deposited and accumulate in sediments. Thus, the research presented below reflects the content of radionuclides in the sediments of the lower reaches of the rivers of the Dnieper-Bug estuary basin.

\section{Objects and methods}

Large-scale studies of modern sediments lower reaches of the Dnieper and the Southern Bug, as well as their lower tributaries - Inhulets and Inhul, respectively, have been carried out. The sediments of the Dnieper-Bug estuary and two reservoirs also were studied: Karachunivsky reservoir on the Inhulets River and Sofiyivsky reservoir on the Inhul River. The choice of the researched area was due to large anthropogenic pressure on hydroecosystems, owing to the location of significant industrial and agricultural capacities in this region (Figure 1).

The sampling points were located along profiles that crossed the investigation objects. The Dnieper river research area was the lower reaches, below the Kakhovka hydroelectric station; 36 samples were selected. The research area of the Southern Bug was from $143 \mathrm{~km}$ above the delta (below the Voznesensk city) and before falling into the Dnieper-Bug estuary; 30 samples were selected. The Inhulets River and the Inhul River both were surveyed from the top to the mouth; 52 and 48 samples were selected, respectively. In the Karachunivsky reservoir 3 profiles were laid and 35 samples were selected; 3 profiles were laid and 29 samples were selected in the Sofiyivsky reservoir. Samples of sediments from the Dnieper-Bug estuary were selected along its perimeter in the section of the coast and Kinburn Peninsula with Kinburn Spit; 32 samples were selected. Overall analyzed 262 samples of sediments.

Samples of sediments were taken with the special cylindrical equipment. Samples with intact structure were taken by soil tube, samples along the shores were taken by drilling. The thickness of the sediment layer selected for analysis was $0,1-0,35 \mathrm{~m}$. The selected samples after drying were subjected to averaging at the points of selection.

The determination of granulometric composition of bottom sediments was carried out on the basis of standard technique by a sieve method. The particle size distribution is the main indicator of the type of bottom sediments, which characterizes the influence of hydrodynamic processes on the structural framework of the samples.

After sieving with the laundering, 12 fractions were allocated, which in the process of analyzing the data were grouped into 4 fractions: psephite, psammite, silts and pelity.

The specific activity of natural $\left({ }^{238} \mathrm{U},{ }^{235} \mathrm{U}\right.$ and ${ }^{232} \mathrm{Th}$, as well as $\left.{ }^{40} \mathrm{~K}\right)$ and artificial $\left({ }^{137} \mathrm{Cs}\right) \gamma$-emitters was determined by means of a gamma-ray spectroscopy system SEG-50 with Ge (Li) detector DGDK-110. Spectroscopy measurements were carried out in the geometry of a "Marinelli conteiner" with a volume of 1 $\mathrm{dm}^{3}$, which provided the maximum sensitivity of the analysis. The specific activity of ${ }^{90} \mathrm{Sr}$ was determined by means a selective $\beta$-radiometer RUB-91. The total $\beta$ activity of bottom sediment samples was determined using a UMF-1500M device (in thin layers with a SBT13 counter). Since the research required a large amount of starting material, data on specific radioactivity were not obtained for some of the research sites.

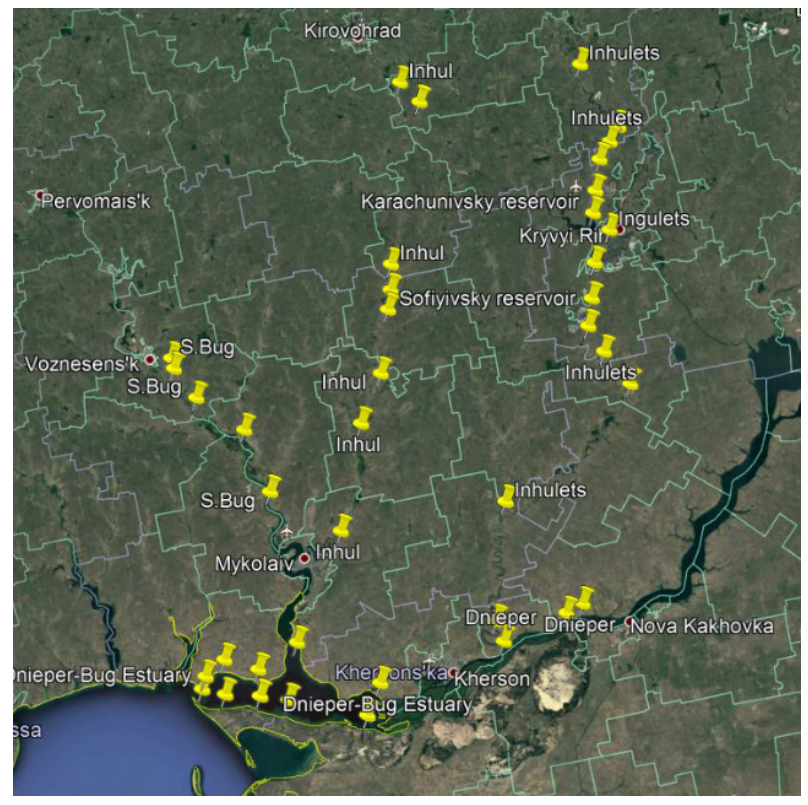

Fig. 1. The research area.

\section{Results and analysis}

The Southern Bug River is the largest river, the basin of which is completely located on the territory of Ukraine. The Southern Bug River originates in the Podillia Upland, then flows along the Black Sea lowlands and flows into the Black Sea, forming the Dnieper-Bug estuary with the Dnieper. A feature of the Southern Bug is the almost complete absence of significant tributaries. The Southern Bug River in the lower reaches has a wide channel and minor meanders. The research area is located in the BugDnieper region of the Black Sea lowland of the Black Sea southern steppe province. On this section of the river 3 transverse profiles were laid. The sediments of the selected samples are dominated by pelity fraction (Figure 2).

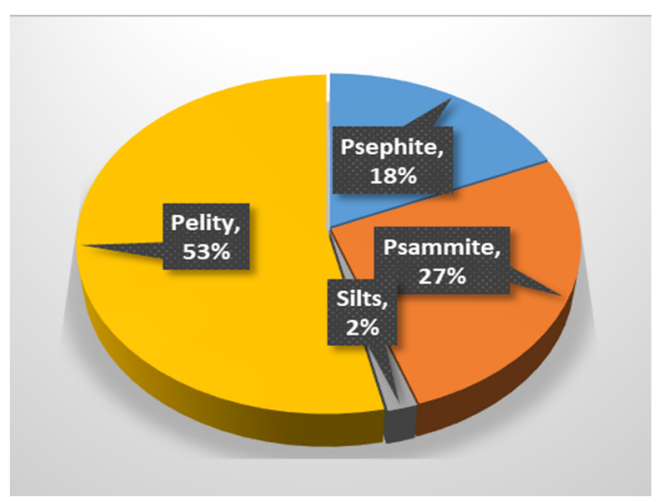

Fig. 2. Granulometric composition of the Southern Buh River sediments. 
The generalized results of determining the specific radioactivity of sediments (by individual radionuclides) of the lower reaches of the Southern Bug River are presented on the diagrams (figures 6-11). The specific activity of natural radioactive elements in sediments of the Southern Bug River occupies an intermediate position between the Dnieper River and the Inhulets and Inhul Rivers. Whereas the content of artificial strontium-137 in the Southern Bug River is the lowest among all surveyed objects. The total $\beta$-activity and isotopic ratios of radionuclides of the sediment samples are presented in table 1 .

Table 1. Total $\beta$-activity $\left(\mathrm{Bq} \cdot \mathrm{kg}^{-1} \mathrm{c}^{-1}\right)$ and isotopic ratios radionuclides of the sediment samples.

\begin{tabular}{|c|c|c|c|c|c|}
\hline \multirow[b]{2}{*}{ Object of study } & \multicolumn{5}{|c|}{ The researched indicators, $M \pm m$} \\
\hline & $\Sigma_{\beta}$ & \begin{tabular}{|l|}
${ }^{238} \mathbf{U} /$ \\
${ }^{226} \mathrm{Ra}$ \\
\end{tabular} & \begin{tabular}{|c|}
${ }^{232} \mathrm{Th} /$ \\
${ }^{238} \mathrm{U}$
\end{tabular} & \begin{tabular}{|l|}
${ }^{212} \mathrm{~Pb} /$ \\
${ }^{214} \mathrm{~Pb}$
\end{tabular} & $\begin{array}{l}{ }^{40} \mathbf{K} / \\
{ }^{238} \mathbf{U}\end{array}$ \\
\hline The Southern Bug & $38,0 \pm 5,0$ & $4,3 \pm 1,0$ & $0,5 \pm 0,1$ & $2,3 \pm 0,5$ & $4,6 \pm 0,9$ \\
\hline The Inhul River & $45,0 \pm 6,5$ & $2,9 \pm 0,5$ & $0,4 \pm 0,1$ & - & $3,7 \pm 0,7$ \\
\hline $\begin{array}{l}\text { The Sofiyivsky } \\
\text { reservoir }\end{array}$ & $50,5 \pm 7,0$ & $3,6 \pm 0,8$ & $0,4 \pm 0,1$ & $1,6 \pm 0,3$ & $3,3 \pm 0,7$ \\
\hline $\begin{array}{l}\text { The Dnieper } \\
\text { River }\end{array}$ & $27,5 \pm 5,0$ & $1,6 \pm 0,6$ & $0,8 \pm 0,2$ & $0,9 \pm 0,3$ & $18,2 \pm 5,1$ \\
\hline $\begin{array}{l}\text { The Inhulets } \\
\text { River }\end{array}$ & $40,0 \pm 7,0$ & $3,6 \pm 1,1$ & $0,4 \pm 0,1$ & $1,4 \pm 0,3$ & $4,3 \pm 0,9$ \\
\hline $\begin{array}{l}\text { The Karachuniv- } \\
\text { sky reservoir }\end{array}$ & $51,2 \pm 8,0$ & $4,8 \pm 1,7$ & $0,3 \pm 0,1$ & $1,3 \pm 0,3$ & $2,1 \pm 0,4$ \\
\hline $\begin{array}{l}\text { The Dnieper-Bug } \\
\text { Estuary }\end{array}$ & $47,8 \pm 5,2$ & $3,1 \pm 0,9$ & $0,6 \pm 0,1$ & $1,5 \pm 0,3$ & $6,2 \pm 2,5$ \\
\hline
\end{tabular}

The Inhul River is the largest left tributary of the Southern Bug, which originates on the southern slope of the Ukrainian Shield. The Inhul River flows into the Bug estuary within the city of Mykolaiv. The territory through which the Inhul River flows belongs to the Dnieper and Kirovohrad metallogenic provinces, within which a considerable number of uranium deposits and manifestations are concentrated [18]. During the works, three sections of the river were investigated. The first of the researched areas, approximately $12 \mathrm{~km}$ long, was located at a distance of $80 \mathrm{~km}$ from the source of the Inhul River, i.e. in the upper reaches. This river section is characterized by a narrow channel with numerous rapids and a fairly fast flow, despite the over-regulation. Upstream the first researched area, on the southern outskirts of Kropyvnytskyi (earlier Kirovohrad), there are dumps of uranium mine of the Michurinsk deposit [19]. The second river section, about $15 \mathrm{~km}$ long (in the middle course of the river), is characterized by an expanded watercourse, slower flow, no rapids. The third, the longest studied area (in the lower reaches of the river) is located outside the Ukrainian Shield. The Sofiyivsky Reservoir, which is built on the Inhul River, was studied separately. The sediments of the first and second sections of Inhul River are represented mainly by psammite, which are replaced by pelity sediments within the Sofiyivsky Reservoir. Pelity fraction of sediments also dominates in the mouth of the Inhul River.

The share of large fractions naturally decreases from the top to the mouth and, accordingly, the share of fine fractions increases. Although on some profiles of the third section are deviations from this pattern, probably due to the features of the relief. The results of determining the particle size distribution of the Inhul River sediments and the Sofiyivsky Reservoir are shown in the Figure 3.

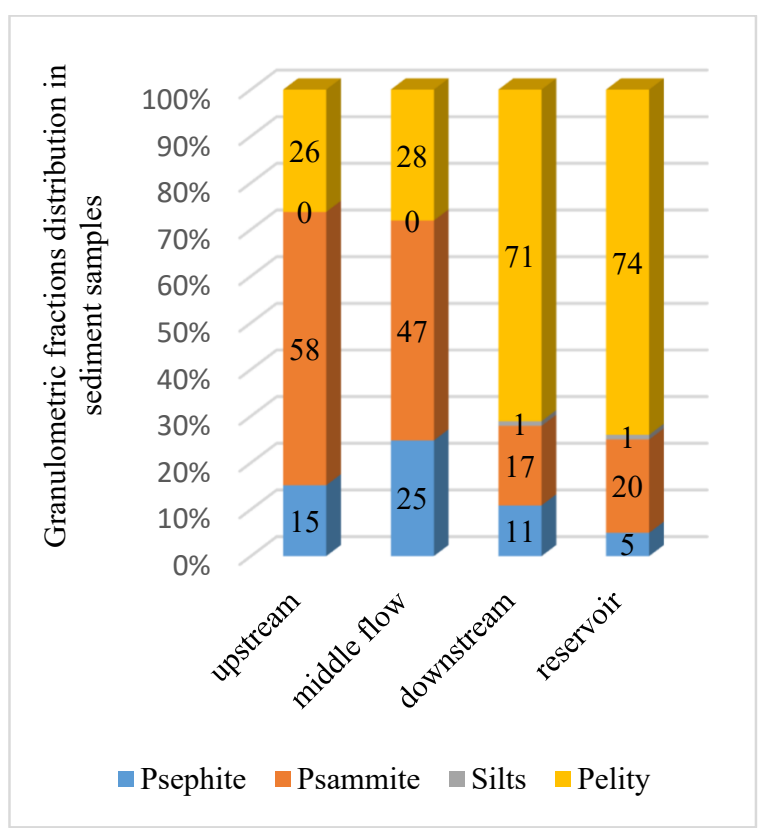

Fig. 3. Granulometric composition of the Inhul River and the Sofiyivsky reservoir sediments.

The results of determining the radionuclides content in the sediments samples of the Inhul River researched areas are presented in table 2 .

Table 2. Specific radioactivity of the Inhul River sediments, $\mathrm{Bq} / \mathrm{kg}$ dry matter.

\begin{tabular}{|c|c|c|c|c|c|c|}
\hline \multirow{2}{*}{ Nuclide } & \multicolumn{2}{|c|}{ Upstream } & \multicolumn{2}{|c|}{ Middle flow } & \multicolumn{2}{c|}{ Downstream } \\
\hline & $\frac{M}{\mathbf{m a x}}$ & $\mathbf{M}$ & $\frac{\mathbf{M i n}}{\mathbf{m a x}}$ & $\mathbf{M}$ & $\frac{\mathbf{M i n}}{\mathbf{m a x}}$ & $\mathbf{M}$ \\
\hline${ }^{238} \mathrm{U}$ & $\frac{61}{107}$ & 79,0 & $\frac{87}{150}$ & 117,0 & $\frac{47}{182}$ & 107,0 \\
\hline${ }^{226} \mathrm{Ra}$ & $\frac{47}{53}$ & 50,0 & $\frac{24}{40}$ & 29,0 & $\frac{23}{34}$ & 27,5 \\
\hline${ }^{232} \mathrm{Th}$ & $\frac{29}{35}$ & 31,7 & $\frac{34}{78}$ & 54,0 & $\frac{33}{96}$ & 46,0 \\
\hline${ }^{235} \mathrm{U}$ & $\frac{5,1}{6,6}$ & 5,6 & $\frac{2,3}{5,4}$ & 3,1 & $\frac{1,8}{5,0}$ & 3,5 \\
\hline${ }^{40} \mathrm{~K}$ & $\frac{191}{355}$ & 285,0 & $\frac{402}{528}$ & 423,0 & $\frac{345}{475}$ & 420,0 \\
\hline${ }^{137} \mathrm{Cs}$ & $\frac{2,5}{4,4}$ & 3,4 & $\frac{1,7}{6,0}$ & 3,7 & $\underline{\frac{0,8}{4,1}}$ & 2,5 \\
\hline
\end{tabular}

*the numerator of the pseudo-fraction is the minimum values of the indicator, the denominator is the maximum

Specific activity of ${ }^{238} \mathrm{U}$ in the sediments gradually increases along the Inhul river flow, as is shown by the results. Similarly, ${ }^{232} \mathrm{Th}$ is distributed, while the content of ${ }^{226} \mathrm{Ra}$ decreases almost twice along the river flow. Other radionuclides demonstrate a multidirectional nature of distribution in the bottom sediment.

The Sofiyivsky Reservoir was built on the Inhul River in the Novobuzhsky District of the Mykolaiv Region in 1968. The channel type reservoir is the largest in volume and closes a cascade of reservoirs on the Inhul River. The 
reservoir is used for drinking water supply. The Sofiyivsky Reservoir sediments are presented by the pelity fraction, the latter is characterized by adsorbing properties, including adsorption of radionuclides (see Figure 6-11).

The Dnieper River is a typical plain river with a slow and calm flow. A powerful anthropogenic offensive significantly changed the configuration of the banks of the Dnieper in the twentieth century. In a large section, this river has turned from clear watercourse with fast stream into a polluted lake-type reservoir, which is gradually but relentlessly silt up (Figure 4). Regulation of the Dnieper River runoff by a cascade of reservoirs has significantly changed the conditions of functioning of the lower river ecosystem.

The spring flood became less expressed, but the unstable runoff regime due to the uneven operation of the Kakhovka hydroelectric power station during the day acquired ecological significance. As a result, even in the main watercourse of the lower reaches of the Dnieper River there are short-term fluctuations in water levels. The negative changes were shown by researches of the ecosystem of the lower Dnieper River in recent years [20, 21]. Eutrophication of watercourse, siltation, overgrowing with aquatic vegetation are determined.

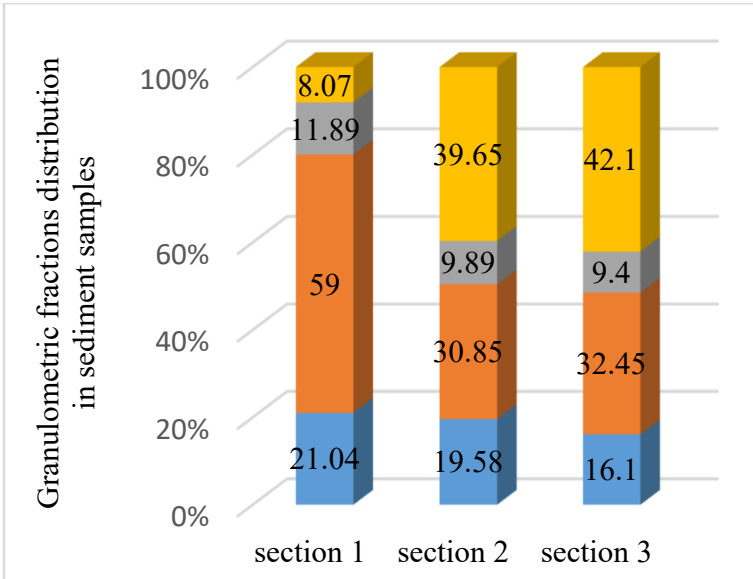

Psephite $\quad$ Psammite $\quad$ Silts $\square$ Pelity

Fig. 4. Granulometric composition of the Dnieper River sediments.

The data of the performed radiological analysis of the Dnieper River are presented in figure 6-11. It should be noted that the profiles were laid down by us were below the entire cascade of Dnieper reservoirs, which in total retain more than $96 \%$ of all terrigenous runoff of the Dnieper. That is why, in our opinion, the specific activity in the bottom sediments of the research section of Dnieper River is the lowest among all the studied objects.

The highest concentrations of ${ }^{137} \mathrm{Cs}$, most likely of Chernobyl origin, however, as well as concentrations of ${ }^{238} \mathrm{U}$ and ${ }^{226} \mathrm{Ra}$ tend to the right less flowing bank of the Dnieper. The equilibrium state in a chain of uranium is characterized by some lack of ${ }^{226} \mathrm{Ra}$. However, given the rather high measurement errors of extremely inactive samples, it can be assumed that these nuclides are in equilibrium. The greatest variability is shown by the ratio ${ }^{40} \mathrm{~K} /{ }^{238} \mathrm{U}$, which is explained by the diversity of the lithological composition of the studied samples. After all, practically "clean" quartz sands border on sandy loams, dark-colored sands, shells, etc. Total $\beta$-radioactivity and isotopic ratios of samples of bottom sediments of the Dnieper River; lower right tributary - the Inhulets River and Karachunivsky reservoir are presented in table 1.

The Inhulets River is a lower right tributary of the Dnieper River, originating on the southern slope of the Ukrainian Shield. Analysis of previous researches [22] allowed to conditionally divide the river valley by zones with different ratio of natural and man-made components in the sediments, which in turn is due to different degrees of anthropogenic presser.

The first zone is the upper reaches of the river, where it flows through metamorphic and ultrametamorphic rocks of the Ukrainian Shield. This area is represented mainly by agricultural areas. The second zone of the Inhulets River is located parallel to the elongated in the meridional direction of the Kryvyi Rih iron ore basin. In this area, the Inhulets River basin is exposed to strong man-made impact from numerous mining and processing enterprises. In the second zone, the Inhulets River receives a tributary - the Zhovta River, which drains the dumps of mines and tailings of hydrometallurgical production of Zhovti Vody [21]. Also in this area is a powerful mining complex of the Kryvyi Rih. The third zone is located below the Kryvyi Rih. The Inhulets River here is characterized by a plain slow-moving current.

The granulometric composition distribution of the researched areas sediments reflects changes in the hydrodynamic regime of the Inhulets River. In the area of the reservoir is a change in the hydrodynamic regime from lotic to lentic, which is recognised in more than $75 \%$ of the pelitic fraction of the sediment (Figure 5).

The minimum and medium particle size recorded for the upper and lower reaches of the river, where the content of man-made material in the sediments is low. Psammite fraction in sediments dominates in the second zone, which is due to the man-made impact of mining and processing enterprises. Our previous studies [22] have determined that this is caused by the presence of a man-made component (tails of ore benefication) in the sediments.

When interpreting the results of radiological analysis of the sediments of the Inhulets River, it should be taken into account that the basin of this river is located within the uranium-bearing province of the south of the Ukrainian Shield. Radiological analysis was performed for bottom sediments of the second (middle flow) and third (downstream) zones [23]. The results of radionuclide content study in samples of the Inhulets River sediments are presented in Table 3. Data analysis shows that the specific activity of all natural radionuclides is higher in the second zone, except for ${ }^{238} \mathrm{U}$.

The results of gamma-spectrometric studies of the Inhulets River sediments demonstrate significant variability in the specific activity of natural radioactive elements. As for technogenic radionuclides in the samples, ${ }^{137} \mathrm{Cs}$ was determined in the second technogenic zone of Inhulets River and Karachunivsky reservoir. 


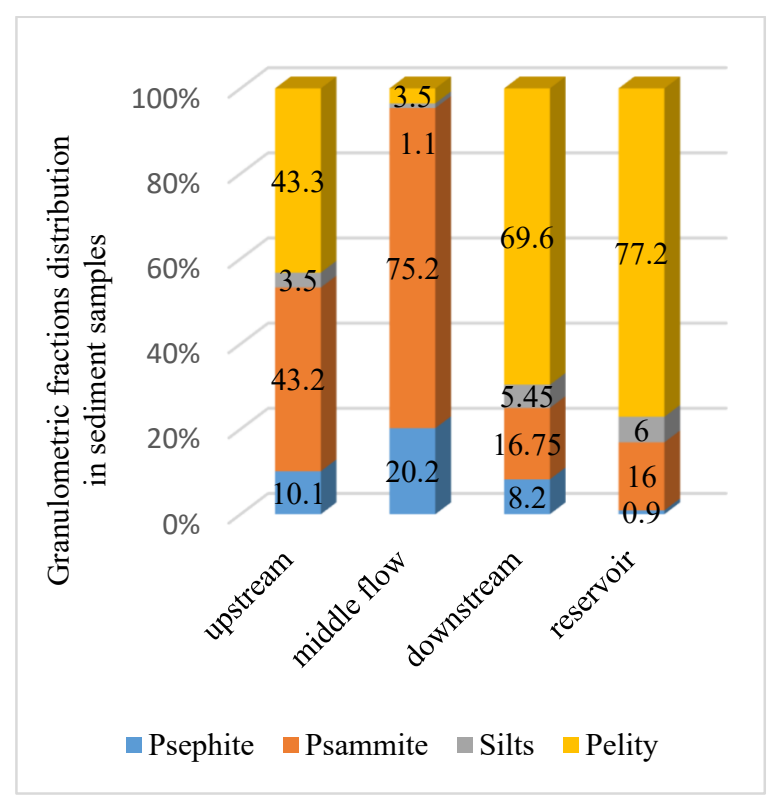

Fig. 5. Granulometric composition of the Inhulets River and Karachunivsky reservoir sediments.

Table 3. Specific radioactivity of the Inhulets River and Karachunivsky reservoir sediments, $\mathrm{Bq} / \mathrm{kg}$ dry matter.

\begin{tabular}{|c|c|c|c|}
\hline \multirow{2}{*}{ Nuclide } & \multicolumn{3}{|c|}{ Average value of specific activity, M \pm m } \\
\cline { 2 - 4 } & $\begin{array}{c}\text { Middle flow } \\
\text { (second zone) }\end{array}$ & $\begin{array}{c}\text { Down-stream } \\
\text { (third zone) }\end{array}$ & $\begin{array}{c}\text { Karachunivsky } \\
\text { reservoir }\end{array}$ \\
\hline${ }^{238} \mathrm{U}$ & $58,0 \pm 22,0$ & $68,0 \pm 10,1$ & $129,0 \pm 15,2$ \\
\hline${ }^{226} \mathrm{Ra}$ & $19,1 \pm 2,2$ & $16,0 \pm 2,2$ & $27,0 \pm 3,1$ \\
\hline${ }^{232} \mathrm{Th}$ & $28,0 \pm 3,2$ & $21,0 \pm 2,1$ & $37,4 \pm 3,9$ \\
\hline${ }^{235} \mathrm{U}$ & $1,7 \pm 0,4$ & $1,4 \pm 0,4$ & $3,4 \pm 0,8$ \\
\hline${ }^{214} \mathrm{~Pb}$ & $19,2 \pm 11,8$ & $16,3 \pm 8,1$ & $15,0 \pm 9,0$ \\
\hline${ }^{214} \mathrm{Bi}$ & $21,3 \pm 10,5$ & $17,0 \pm 10,4$ & $14,0 \pm 12,0$ \\
\hline${ }^{228} \mathrm{Ac}$ & $30,1 \pm 17,8$ & $21,3 \pm 9,2$ & $19,0 \pm 11,0$ \\
\hline${ }^{212} \mathrm{~Pb}$ & $28,0 \pm 9,9$ & $21,0 \pm 12,0$ & $20,0 \pm 9,7$ \\
\hline${ }^{212} \mathrm{Bi}$ & $46,4 \pm 17,2$ & $24,1 \pm 15,4$ & $*$ bml \\
\hline${ }^{40} \mathrm{~K}$ & $297,5 \pm 37,0$ & $241,0 \pm 31,7$ & $268,5 \pm 14,0$ \\
\hline${ }^{137} \mathrm{Cs}$ & $4,6 \pm 0,7$ & $* \mathrm{bml}$ & $42,5 \pm 9,2$ \\
\hline
\end{tabular}

*bml - below the measurement limit

The Karachunivsky reservoir is the closing reservoir in the cascade on the Inhulets River and due to its largest volume serves as the main regulator of river flow. The reservoir is used for drinking water supply, as well as irrigation of adjacent lands. Construction of the Karachunivsky reservoir on the Inhulets River began in 1932 and commissioned in 1939. It is located in the zone of influence of technogenic factors of the mining complex of Kryvyi Rih. During 1950-1958 years, the reservoir received its modern shape. The reservoir is very silted up. Thus, the age of sediments of the most stagnant part reservoir exceeds 50 years. In the studied samples, the uranium content usually significantly exceeded the radium content. It is known that the mobility of the latter in the zone of hypergenesis is somewhat limited, except for environments with low $\mathrm{pH}$ values.

The specific activity of ${ }^{137} \mathrm{Cs}$ of Chernobyl origin varies widely. Since caesium-137 migrates mainly in the form of a suspension (adsorbed on clay pelitic particles), its accumulation sites in bottom sediments coincide with stagnant zones, where the flow is minimal and suspended particles fall out of the water. The specific activity of ${ }^{137} \mathrm{Cs}$ in the Karachunivsky reservoir exceeds similar values in other researched rivers on an average in ten times (Figure 11). Also, ${ }^{90} \mathrm{Sr}$ of Chernobyl genesis was determined in single samples of precipitation from the Karachunivsky reservoir. In contrast, natural ${ }^{226} \mathrm{Ra}$ is somewhat chemically similar to calcium and strontium. It is known that molluses build their shells from calcium compounds and are also able to capture strontium and radium from solutions of compounds. Thus, radium-226 can be eliminated from the solution and bound in the shell material. Compounds of uranium and thorium are not usually used by living organisms to build a skeleton. The accumulation of the above-mentioned elements in biogenic sediments is mostly associated with later stages of lithogenesis and occurs due to purely chemical processes.

The Dnieper-Bug estuary is the largest estuary of the north-western Black Sea coast and at the same time it's a complex natural open type hydroecosystem. In the estuary, as in the water area with limited water exchange, changes occur in hydrological, hydrochemical and hydrobiological conditions of sedimentation from river to sea, the effect of the geochemical barrier is enhanced. The estuary is a place of intensive transformation of sedimentary material in the form of suspended matter, the main source of which is terrigenous runoff. The most of the suspended matter is retained at the stage of mixing river and sea water and enters the sediment. Subsequent transformation of sedimentary material takes place on the river-sea geochemical barrier. Sedimentation substances in open estuaries have different origins. First of all, these are the products of river runoff, abrasions of shores and seabed, the development of bios in the estuaries themselves, as well as substances brought by seawater. The most common type of sediments in the Dnieper-Bug estuary is siltstone silt with a medium degree of sorting, which essentially constitutes the lithological background of bottom sediments. Demolition of this material occurs mainly due to the Dnieper and the Southern Bug [24, 25].

The granulometric composition of the bottom sediments of the Dnieper-Bug estuary is heterogeneous. Samples taken along the Kinburn Peninsula and Kinburn Spit are represented by homogeneous well-sorted quartz sand, which does not contain clay impurities and is $98 \%$ composed of psammites. Samples from the section of coast are represented by different particle size classes. So, psammites dominate in the samples taken on the shelf and pelites predominate in the samples taken on the shore. The latter are composed of fine clay particles. This fact is probably the result of constant transgression of the sea. The samples from the profile that crosses the mouth of the Southern Bug are exceptions. In these samples, psammites predominate in the granulometric composition distribution.

The results of determination of radionuclides in the bottom sediments of the Dnieper-Bug estuary are shown in table 4. Distribution of radionuclides in the sediments depending on the particle size was clearly demonstrated in the presented results. 
Table 4. Specific radioactivity of the Dnieper-Bug estuary sediments, $\mathrm{Bq} / \mathrm{kg}$ dry matter.

\begin{tabular}{|c|c|c|}
\hline \multirow{2}{*}{ Nuclide } & \multicolumn{2}{|c|}{ The researched district } \\
\cline { 2 - 3 } & Section of the coast & $\begin{array}{c}\text { Kinburn Spit and } \\
\text { Kinburn Peninsula }\end{array}$ \\
\cline { 2 - 3 } & $\mathbf{M} \pm \mathbf{m}$ & $\mathbf{M} \pm \mathbf{m}$ \\
\hline${ }^{238} \mathrm{U}$ & $69,6 \pm 30,5$ & $21,9 \pm 7,1$ \\
\hline${ }^{226} \mathrm{Ra}$ & $22,4 \pm 4,2$ & $11,1 \pm 2,1$ \\
\hline${ }^{234} \mathrm{Th}$ & $55,6 \pm 10,5$ & $28,2 \pm 7,3$ \\
\hline${ }^{235} \mathrm{U}$ & $1,7 \pm 0,5$ & $0,6 \pm 0,2$ \\
\hline${ }^{214} \mathrm{~Pb}$ & $18,2 \pm 2,8$ & $15,1 \pm 3,1$ \\
\hline${ }^{214} \mathrm{Bi}$ & $17,5 \pm 2,0$ & $14,4 \pm 1,5$ \\
\hline${ }^{228} \mathrm{Ac}$ & $28,1 \pm 3,1$ & $16,5 \pm 1,5$ \\
\hline${ }^{212} \mathrm{~Pb}$ & $27,7 \pm 3,0$ & $15,5 \pm 1,7$ \\
\hline${ }^{212} \mathrm{Bi}$ & $32,6 \pm 6,7$ & $18,8 \pm 6,1$ \\
\hline${ }^{208} \mathrm{Tl}$ & $11,1 \pm 1,5$ & $6,4 \pm 0,7$ \\
\hline${ }^{40} \mathrm{~K}$ & $350,0 \pm 29,0$ & $214,0 \pm 20,5$ \\
\hline${ }^{137} \mathrm{Cs}$ & $2,0 \pm 0,5$ & $0,5 \pm 0,2$ \\
\hline
\end{tabular}

Thus, the specific activity of ${ }^{238} \mathrm{U}$ from the section of coast samples on an average in three times more than from Kinburn Spit samples. ${ }^{234} \mathrm{Th}$ in the "continental" samples is slightly higher than in the samples from the spit (on an average in two times). In general, the content in the sediments samples of the Dnieper-Bug estuary ${ }^{228} \mathrm{Ac}$ is stable and relatively low. As for ${ }^{235} \mathrm{U}$ and its decay products, it content in the researched samples is quite insignificant, although it varies in a wide range from 0,18 to $2,83 \mathrm{~Bq} / \mathrm{kg}$.

Relatively low concentration of ${ }^{137} \mathrm{Cs}$ of Chernobyl origin was determined, in the studied samples of sediments, although the specific activity of this nuclide varies widely - the fluctuations were about 15 times. Due to the predominance of psammitic fraction in bottom sediment samples, this may lead to low concentrations of ${ }^{137} \mathrm{Cs}$.

Determination of total $\beta$-activity showed a range of variations from 16,5 to $96,0 \mathrm{~Bq} \cdot \mathrm{kg}^{-1} \mathrm{c}^{-1}$. The difference between the samples taken from the water and on the shore is about 2 times.

\section{Discussion}

The origin of sediments is essential in interpreting the results of $\gamma$-spectrometric measurements. The state of equilibrium in the natural decay chains of uranium and thorium depends on how certain deposits were formed by mechanical precipitation of the suspension or by chemical or biochemical precipitation of the solution. If such an equilibrium exists, the specific activities of all members of the radioactive chain are equal to each other, and vice versa, when deposits are formed by chemical accumulation of aqueous solutions of radionuclides different in chemical properties - age equilibrium cannot exist in principle. Given the significantly different yields of gamma quanta on the decay of a radionuclide, the sensitivity of their determination by the $\gamma$-spectrometric method varies in a very wide range. Under the same measurement conditions, the daughter products ${ }^{226} \mathrm{Ra}$ are determined with the highest sensitivity: ${ }^{214} \mathrm{~Pb}$ and ${ }^{214} \mathrm{Bi}$; ${ }^{137} \mathrm{Cs}$; subsidiaries ${ }^{232} \mathrm{Th}:{ }^{212} \mathrm{~Pb},{ }^{228} \mathrm{Ac},{ }^{212} \mathrm{Bi}$ and ${ }^{40} \mathrm{~K}$. Much worse conditions for determining the nearest uranium decay products: ${ }^{234} \mathrm{Th}$ and ${ }^{234 \mathrm{~m}} \mathrm{~Pa}$. However, at high concentrations of this element in the studied samples, the use of ${ }^{234 \mathrm{~m}} \mathrm{~Pa}$ is quite appropriate and justified, because this nuclide is almost always in equilibrium with the parent ${ }^{238} \mathrm{U}$.

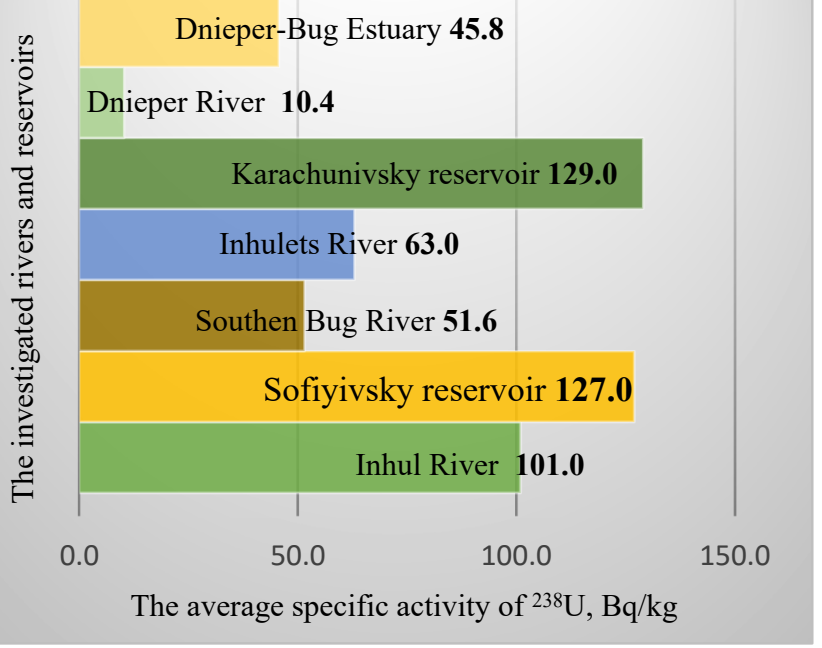

Fig. 6. The averaged values of ${ }^{238} \mathrm{U}$ specific activity in the samples of sediments.

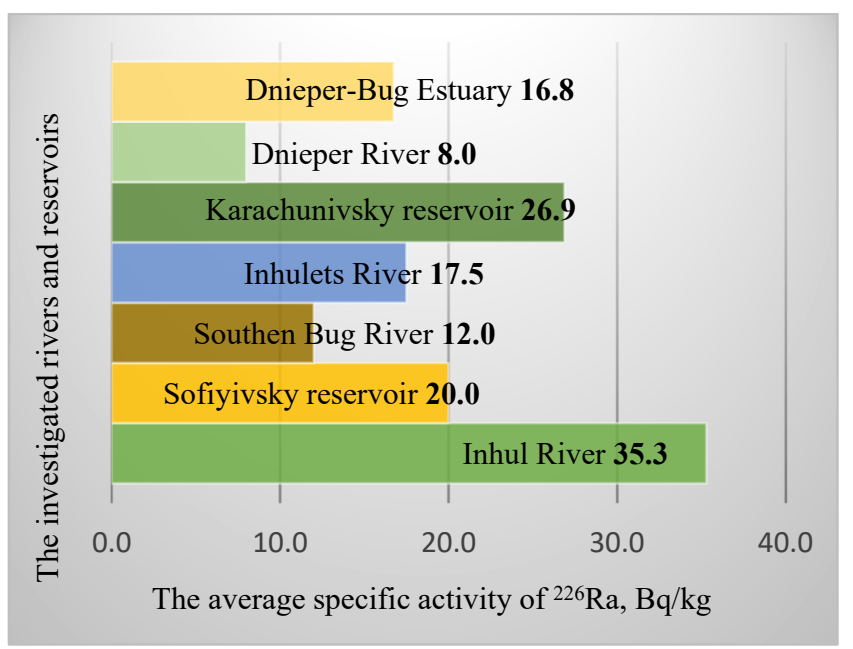

Fig. 7. The averaged values of ${ }^{226} \mathrm{Ra}$ specific activity in the samples of sediments.

The mobility and bioavailability of radionuclides of accidental origin in the terrestrial and aquatic environment are governed by their chemical forms in fallout and site-specific environmental characteristics. The latter determine rates of leaching, fixationremobilisation, as well as sorption-desorption of the mobile fraction (its solid-liquid distribution). After deposition on the surface of water bodies, radionuclides are subject to physicochemical and biological processes, which leads to changes in their speciation. Dissolved radionuclide is adsorbed on the solid phase by ion exchange. Exchangeable radiocaesium transforms into the fixed form [26]. 


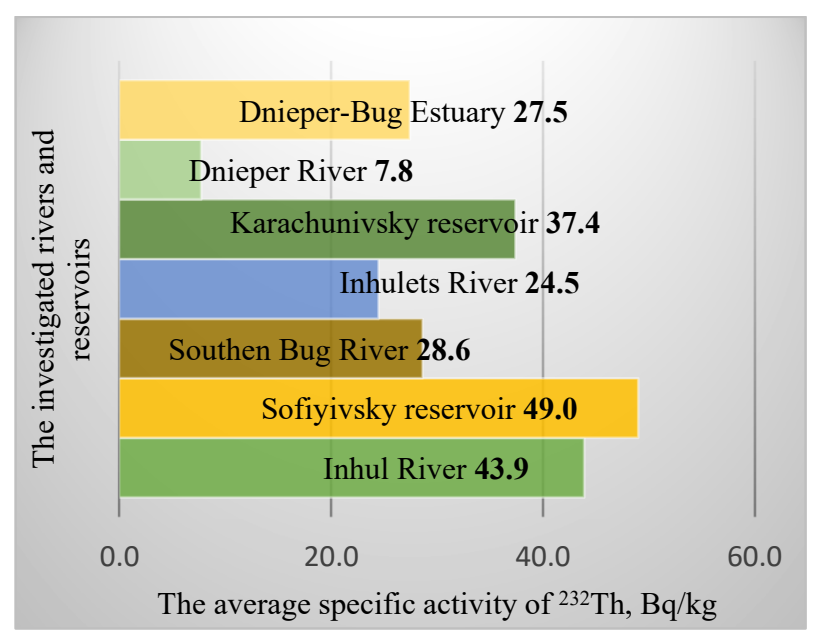

Fig. 8. The averaged values of ${ }^{232} \mathrm{Th}$ specific activity in the samples of sediments.

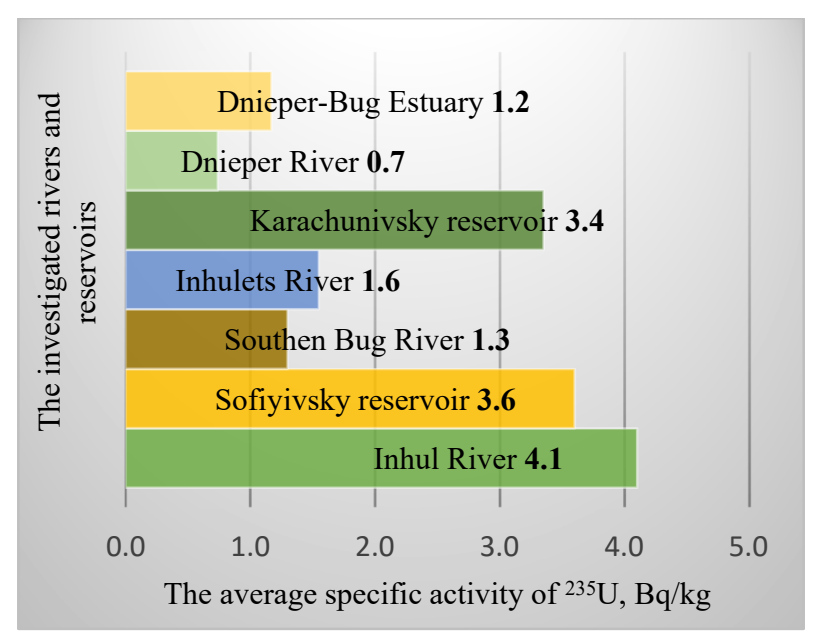

Fig. 9. The averaged values of ${ }^{235} \mathrm{U}$ specific activity in the samples of sediments.

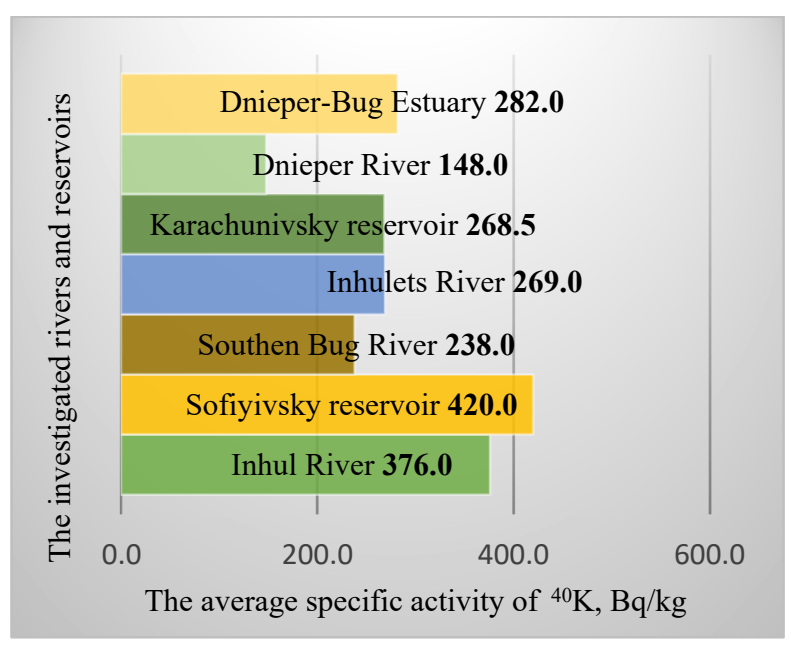

Fig. 10. The averaged values of ${ }^{40} \mathrm{~K}$ specific activity in the samples of sediments.

It is now well established that the high retention of radiocaesium in soil and bottom sediments is largely determined by two different processes: fixation and reversible selective sorption. Fixation describes the "permanent" (or at least long-term) replacement of interlattice K- by Cs-ions due to collapse of expanded edges of mineral's crystal lattice interlayers.

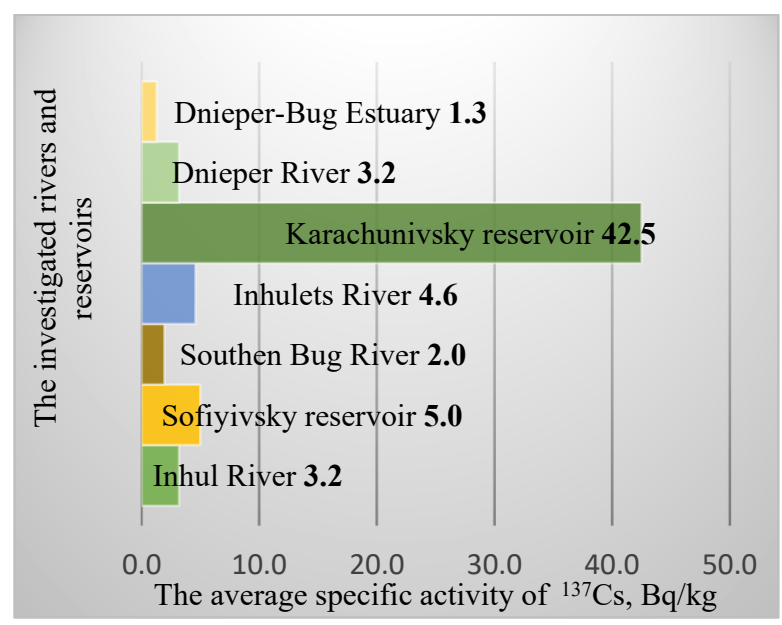

Fig. 11. The averaged values of ${ }^{137} \mathrm{Cs}$ specific activity in the samples of sediments.

The data for long-term transformation of chemical forms of radionuclides in soil and sediment in the longterm after the Chernobyl accident indicate the existence of a remobilization process that is the reverse of fixation [27]. After deposition of radiocesium the fraction of its exchangeable form does not decrease to zero, as should happen during irreversible fixation, in theory. Radiocesium decreases to a certain level, independent of the amount of radionuclide applied, and then does not change significantly because of an equilibrium steady state between fixated and remobilized fractions [28].

\section{Conclusions}

1. The data obtained in this research can serve as a baseline data in natural radionuclides concentration in sediments rivers flowing into the Dnieper-Bug estuary. The obtained data can also be used for further monitoring of the specific activity of man-made radionuclides, in particular ${ }^{137} \mathrm{Cs}$.

2. The data shows a significant variation in grain size and at the same time make it possible to identify a tendency to increase pelitic fraction in sediments. According to this indicator can arrange rivers in the following row: Dnieper $<$ Southern Bug $<$ Inhulets $<$ Inhul. However, despite the tendency to silting, in general, natural facial distribution of sediment has preserved, except are areas within a border of large industrial cities (e.g. Inhulets within Kryvyi Rih).

3. The presence of natural radioactive elements in river sediments is due to geological, hydrological and chemical factors. Purposeful sampling into undisturbed sections near the dam of reservoirs makes it possible to reconstruct the history of the formation of radioactive contamination of bottom sediments and, accordingly, catchment areas.

4. In general, data about natural radioactive elements in the sediments rivers flowing Dnieper-Bug estuary 
obtained in this research demonstrates moderate specific activity. Which, however, clearly correlates with the granulometric composition of bottom sediments.

5. The radiocaesium of Chernobyl origin determined by us is contained in the sediments of all studied water bodies. The places of its greatest concentration coincide with the stagnant areas of reservoirs, in which the sediment is represented mainly by the pelitic fraction.

6. The section of the E-40 waterway, which plans to construct from the Kiev reservoir to the Black Sea will require regular dredging work. Sediments contaminated by cesium-137 of Chernobyl origin have been slowly covered by less contaminated and clean sediments, offering a natural shield to this man-made pollutant. The International Atomic Energy Agency (IAEA) recommends leaving these sediments in place and avoiding processes that will lead to their resuspension and entrance into water.

\section{References}

1. F. Warner, R. Harrison Puty myhratsyy iskusstvennykh radyonuklydov $v$ okruzhaiushchei srede. Radyoekolohyia posle Chernobylia (Migration routes of artificial radionuclides in the environment. Radioecology after Chernobyl) (Mir, Moscow, 1999).

2. A.V. Trapeznykov ${ }^{60} \mathrm{Co},{ }^{90} \mathrm{Sr},{ }^{137} \mathrm{Cs},{ }^{239-240} \mathrm{Pu} \quad v$ presnovodnykh ekosystemakh $\left({ }^{60} \mathrm{Co},{ }^{90} \mathrm{Sr},{ }^{137} \mathrm{Cs}\right.$ and ${ }^{239-240} \mathrm{Pu}$ in the freshwater ecosystems) (PH: AcademNauka, Yekaterinburg, 2010).

3. Chernobyl fears resurface over contract to dredge river in exclusion zone. (2020), Accessed https://www.theguardian.com/environment/2020/dec /23/chernobyl-fears-resurface-over-contract-todredge-river-in-exclusion-zone-aoe

4. E-40 waterway could pose increased radiation risk for millions of people. (2020), Accessed https://savepolesia.org/wpcontent/uploads/2020/04/SavePolesia_Factsheet_E4 0-could-expose-people-to- radiation.pdf

5. D. Boilley, A. Pigrée, P. Barbey. Chernobyl heritage and the E-40 trans-Europe waterway. (Hérouville, Saint-Clair, 2020).

6. G. Suresh, V. Ramasamy, V. Meenakshisundaram, Applied Radiation and Isotopes 3 (70), 556 (2012).

7. A. A. Singleton, A. H. Schmidt, P. R. Bierman, Geochimica et Cosmochimica Acta 197, 71 (2017).

8. T. Semizhon, S. Röllin, Y. Spasova, E. Klemt, Journal of Environmental Radioactivity 5 (101), 385 (2010).

9. A. V. Trapeznikov, V.N. Trapeznikova, A.V. Korzhavin, Radiation biology. Radioecology. 55 (3), 320 (2015).

10. E. Yu. Yakovlev, A. I. Malov, S. V. Druzhinin, E. N. Zykova, A. S. Orlov, Journal of Environmental Radioactivity 213, 106 (2020).

11. M. Fallah, S. Jahangiri, H. Janadeleh, M. A. Kameli, Microchemical Journal 146, 1090 (2019).
12. O. I. Symranych, O. Yu. Sukhareva, S. M. Sukharev, Methods and objects of chemical analysis 3 (9), 145 (2014).

13. F. Eyrolle, H. Lepage, Ch. Antonelli, A.Morereau, C. Cossonnet, Science of the Total Environment 723, 137 (2020).

14. Q. Wang, J. Song, X. Li, H. Yuan, N. Li, L. Cao, Journal of Environmental Radioactivity 162-163, 87 (2016).

15. H. Baltas, M. Sirin, G. Dalgic, U. Cevik, Journal of Marine Systems 177, 21 (2018).

16. S. B. Gulin, V. Yu. Proskurnin, I.G. Sidorov, Journal of Environmental Radioactivity 203, 154 (2019).

17. Analytical review of the state of technogenic and natural security in Ukraine in 2015 (2015) Accessed: http:/www.dsns.gov.ua/ua/Analitichniyoglyad-stanu-tehnogennoyi-ta-prirodnoyibezpeki-v-Ukrayini-za-2015-rik.html

18. Ya. N. Belevtsev, V.B. Koval Henetycheskye typy y zakonomernosty razmeshchenyia uranovykh mestorozhdenyi Ukrayny (Genetic types and patterns of location of uranium deposits in Ukraine) (PH: Naukova Dumka, Kyiv, 1995).

19. V. O. Shumlyansky, A. G. Subbotin, A. H. Bakarzhiev Tekhnohenne zabrudnennia radioaktyvnymy elementamy rodovyshch korysnykh kopalyn (Man-caused contamination by radioactive elements at mineral deposits (PH: Knowledge of Ukraine, Kyiv, 2003).

20. V. M. Timchenko, V. L. Gilman, E.I. Korzhov Hidroekolohichni zasady polipshennia stanu ekosystemy ponyzzia Dnipra (Hydroecological principles of improving the ecosystem of the lower reaches of the Dnieper). Paper presented at the $3 \mathrm{~d}$ International scientific conference «Modern problems of hydroecology», Kherson, 17-19 May 2012.

21. O. Voitsekhovitch, Y. Soroka, T. Lavrova, Radioactivity in the Environment 8, 206 (2006).

22. I. M. Malakhov, T.M. Alokhina, V.V. Ivanchenko, Geology and Mineral Resources of the World Ocean 2 (20), 69 (2010).

23. T. M. Alokhina, V. V. Gudzenko Radionuklidy $v$ vidkladakh richok pivdnia Ukrainy (Radionuclides in sediments of rivers in the South of Ukraine) Paper presented at the $7^{\text {th }}$ International scientific-practical conference «Heavy metals and radionuclides in the environment», Semipalatinsk, 4-8 October 2012.

24. O. Yu. Mitropolsky, E. I. Nasedkin, N.P. Oskina Ekoheokhymyia Chernoho moria (Ecogeochemistry of the Black Sea) (PH: Naukova Dumka, Kyiv, 2006).

25. E.F. Shnyukov Heolohyia Chernoho y Azovskoho morei (Geology of the Black and Azov Seas) (PH: Naukova Dumka, Kyiv, 2000).

26. A. V. Konoplev, A. A. Bulgakov, Atomic Energy 86, 136 (2000). 
27. J. T. Smith, R. N. Comans, D. G Ireland, L. Nolan, Applied Geochemistry 6 (15), 833 (2000).

28. A.de Koning, R. N. Comans, Geochimica et Cosmochimica Acta. 13 (68), 2815 (2004).

29. N. A. Beresford, S. Fesenko, A. Konoplev, L. Skuterud, J.T. Smith, G. Voigt, Journal of Environmental Radioactivity 157, 77 (2016). 